\title{
Management of Functional Constipation in Children: Therapy in Practice
}

\author{
Ilan J. N. Koppen ${ }^{1} \cdot$ Laureen A. Lammers $^{2} \cdot$ Marc A. Benninga $^{1} \cdot$ Merit M. Tabbers $^{1}$
}

Published online: 11 August 2015

(C) The Author(s) 2015. This article is published with open access at Springerlink.com

\begin{abstract}
Functional constipation is a common healthcare problem among children worldwide and accounts for high healthcare usage and costs. Functional constipation is a clinical diagnosis; the evaluation primarily consists of a thorough medical history and a complete physical examination. Additional investigations are not necessary in most cases. Treatment consists of non-pharmacological and pharmacological interventions. Non-pharmacological interventions involve education and demystification, toilet training (with a reward system), and a defecation diary. Pharmacological treatment comprises three steps: disimpaction, maintenance treatment, and weaning. The treatment of first choice is oral laxatives, preferably polyethylene glycol. When this is insufficient, other therapeutic agents are available. This review discusses the evaluation and management of functional constipation in the pediatric population and provides a summary of drug treatment options.
\end{abstract}

Ilan J. N. Koppen

i.j.koppen@amc.nl

Merit M. Tabbers

m.m.tabbers@amc.uva.nl

1 Department of Pediatric Gastroenterology and Nutrition, Emma Children's Hospital/Academic Medical Center, Meibergdreef 9, Room C2-312, 1105 AZ Amsterdam, The Netherlands

2 Department of Hospital Pharmacy, Academic Medical Center, Meibergdreef 9, 1105 AZ Amsterdam, The Netherlands

\section{Key Points}

Functional constipation in children is a commonly occurring disorder. It is a clinical diagnosis based on medical history and physical examination.

In the treatment of functional constipation, the medication of first choice for both disimpaction and maintenance treatment is polyethylene glycol.

Other therapeutic agents (e.g., stimulant laxatives or lubricants) may be useful as additional or secondline therapy if adequate treatment with oral laxatives is insufficient.

\section{Introduction}

Functional constipation (FC) is a common pediatric healthcare problem worldwide, with reported prevalences ranging between 0.7 and $29.6 \%$ and a mean female-tomale ratio of $2.1: 1$ [1]. FC is characterized by infrequent bowel movements, hard and/or large stools, painful defecation, and fecal incontinence, and is often accompanied by abdominal pain [2]. These symptoms can have a significant impact on a child's well-being and health-related quality of life [3-9]. It is estimated that constipation in children accounts for $3 \%$ of visits to a general pediatrician and up to $25 \%$ of visits to a pediatric gastroenterologist in the USA [10]. Furthermore, healthcare costs for children with constipation are higher than those for control subjects, mostly because of ambulatory care costs and, to a lesser degree, costs related to hospitalizations and emergency room visits [11]. Estimations of the economic burden 
caused by childhood FC vary between studies $[12,13]$. In the USA, the total additional costs for childhood constipation have been estimated to be US\$3.9 billion per year [13]. Furthermore, the same study revealed that the mean total unadjusted annual expenditure for children with constipation was three times higher than that for children without constipation (US\$3430/year versus US\$1099/year) [13].

This review focuses on the current approach to management of FC in the pediatric population and provides practical guidance, including a summary of drug treatment options.

\subsection{Definition}

To define FC and other functional defecation disorders in children, the Rome III criteria were defined by a group of pediatric gastroenterology experts in 2006 [14]. The Rome III criteria for FC in children differentiate between children up to 4 years of age and children aged $\geq 4$ years. These criteria are listed in Table 1. In the spring of 2016, the newly revised Rome IV criteria are expected to be published.

FC not responding to optimal conventional treatment for at least 3 months is defined as intractable constipation [15].

\subsection{Pathophysiology}

In approximately $95 \%$ of children with constipation, no organic cause can be identified [15]. These children suffer from FC. In the remainder of cases, constipation has an organic cause, such as a metabolic or endocrine disorder, anorectal anomalies, neuromuscular diseases, or Hirschsprung's disease [16].

The pathophysiology of FC is still incompletely understood but is likely to be multifactorial. One important etiological factor, especially in young children, is withholding behavior, frequently occurring after a negative experience-e.g., a hard, painful, and/or frightening bowel movement [17]. Stool-withholding behavior can lead to fecal impaction-the presence of a large fecal mass in either the rectum or the abdomen. Moreover, fecal impaction often causes overflow fecal incontinence, which is involuntary loss of soft stools that pass an obstructing fecal mass.

Psychosocial factors, such as major life events, may play an important role in the pathophysiology of FC. Furthermore, behavioral disorders, such as autism spectrum disorders and attention deficit/hyperactivity disorder, are associated with a higher risk of childhood constipation [18, 19]. Lastly, factors such as socioeconomic status, educational level, and parental child-rearing attitudes have been designated as influencing factors in the pathophysiology of FC in children $[1,20]$.

\section{Evaluation}

Evaluation of childhood constipation primarily consists of a thorough medical history and a complete physical examination [15]. In most cases, additional investigations are not necessary.

\subsection{Medical History}

The medical history should focus on the child's bowel habits. Questions should address the defecation frequency, number of episodes and timing of fecal incontinence, stool consistency, withholding behavior, and painful and/or hard bowel movements (see Table 1). The Modified Bristol Stool Form Scale for Children can be used to define stool consistency [21]. A daily bowel diary can be useful to gather more reliable information about a child's bowel habits, since recall of bowel habits has proven to be inaccurate [22]. Furthermore, information has to be sought on coexistence of abdominal pain, dietary history, changes in appetite, the presence of nausea and/or vomiting, and other accompanying symptoms. Alarm symptoms suggestive of

Table 1 Rome III criteria for functional constipation [14]

\begin{tabular}{|c|c|}
\hline Age $<4$ years $^{\mathrm{a}}$ & Developmental age of $\geq 4$ years $^{b}$ \\
\hline 1. $<3$ defecations per week & 1. $<3$ defecations in the toilet per week \\
\hline \multirow{2}{*}{$\begin{array}{l}\text { 2. } \geq 1 \text { episode of fecal incontinence per week after acquisition of toileting } \\
\text { skills }\end{array}$} & 2. $\geq 1$ episode of fecal incontinence per week \\
\hline & 3. History of retentive posturing or excessive volitional stool \\
\hline 3. History of excessive stool retention & retention \\
\hline 4. History of painful or hard bowel movements & 4. History of painful or hard bowel movements \\
\hline 5. Presence of a large fecal mass in the rectum & 5. Presence of a large fecal mass in the rectum \\
\hline 6. History of large diameter stools, which may obstruct the toilet & 6. History of large diameter stools, which may obstruct the toilet \\
\hline
\end{tabular}

${ }^{\text {a }}$ Must fulfill $\geq 2$ criteria for $\geq 1$ month prior to diagnosis

b Must fulfill $\geq 2$ criteria at least once per week for $\geq 2$ months prior to diagnosis, with insufficient criteria for diagnosis of irritable bowel syndrome 
an organic cause include-but are not limited to-delayed passage of meconium, a history of blood in the stools without the presence of fissures, failure to thrive, and severe abdominal distension [15].

Details about the onset of symptoms, duration of symptoms, and precipitating factors can provide more insight into the pathophysiology. The duration until passage of the first meconium, the presence of fissures during infancy, and feeding-type-change-related defecation alterations in the past may provide valuable insights. It is also important to obtain information about the child's age at successful toilet training. Special attention to psychosocial problems and life events is warranted. Often, the start of symptoms coincides with life events such as the divorce of parents or the birth of a younger sibling.

A detailed medication history should include the use and efficacy of oral laxatives, enemas, and behavioral treatment, and the use of other medication that may influence bowel movements.

For an elaborate disquisition on possible underlying organic causes and alarm symptoms, readers are referred to the evidence-based recommendations published by the North American Society for Pediatric Gastroenterology, Hepatology, and Nutrition (NASPGHAN) and the European Society for Pediatric Gastroenterology, Hepatology, and Nutrition (ESPGHAN) [15].

\subsection{Physical Examination}

Besides assessing weight and height, the physical examination primarily consists of abdominal examination, inspection of the perianal region, examination of the lumbosacral region, and neurological examination.

Abdominal examination mainly focuses on detection of a palpable fecal mass. During perianal inspection, the physician checks for anatomic abnormalities, perianal feces, fissures, scars, and erythema. Fissures may indicate hard and/or large diameter stools. Digital rectal examination provides valuable information on the presence of a rectal fecal mass, anorectal sensation, and sphincter tone [15]. During examination of the lumbosacral region, inspection should focus on the presence of a dimple, a tuft of hair, or a gluteal cleft deviation. A lower limb neuromuscular examination provides information on the neurological integrity of the lumbosacral region.

A history of smearing feces or detection of fissures and hematomas during physical examination should always raise suspicion of sexual abuse. Since the physical examination findings of most pediatric sexual abuse victims are within normal limits, special attention should be paid to abnormal behavior during physical examination (e.g., sexual acting out, extreme fear) [23].

\subsection{Laboratory Testing}

Standard laboratory testing is not necessary in the workup for FC [15].

\subsection{Radiology}

Radiological testing is not required to diagnose childhood constipation [15].

\subsubsection{Abdominal Radiography}

Although it is still frequently used by many physicians, a "plain" abdominal X-ray is not the appropriate tool to demonstrate constipation. Unsatisfactory sensitivity and specificity rates, as well as low inter- and intra-observer reliability, have been reported for the different scoring systems (Barr, Leech, Blethyn) that are used to evaluate these abdominal X-rays [15, 24].

\subsubsection{Colonic Transit Time}

The colonic transit time (CTT) can be determined to evaluate colonic motility. The most widely used method is the marker test; this uses radiopaque markers, which are ingested orally and visualized with an abdominal X-ray [2426]. Two other, less frequently used, methods to determine the CTT are radionuclide scintigraphy and wireless motility capsules [27]. There is no evidence for routine use of the CTT in the diagnostic workup of FC [15]. An extremely prolonged CTT ( $>100 \mathrm{~h})$, does however, indicate a severe form of constipation [26]. In situations in which the diagnosis is not clear, a colonic transit study may be useful to discriminate between functional constipation and functional nonretentive fecal incontinence, a disorder characterized by fecal incontinence without signs of constipation [15, 25, 28].

\subsection{Other Investigations}

Other investigations, such as rectal ultrasonography, magnetic resonance imaging (MRI), rectal barostat, barium enemas, anorectal manometry, colonic manometry, colonic scintigraphy, and rectal/colonic biopsies, are sometimes indicated but do not belong in the routine workup of constipation and therefore go beyond the scope of this review.

\section{Non-Pharmacological Treatment}

\subsection{Education}

Education and demystification are the first steps in the nonpharmacological treatment of FC [29]. Information on the 
prevalence, symptoms, initiating and perpetuating (risk) factors, treatment options, and prognosis should be provided. Children should be actively involved in this conversation if allowed by their developmental age. A non-accusatory approach of both physicians and parents is of key importance [29]. Children may feel guilty or embarrassed, especially about fecal incontinence episodes; it is therefore important to explain the pathophysiology of overflow incontinence. Childhood constipation is often a long-lasting problem, which should be explained to both parents and patients.

\subsection{Toilet Training, Reward System, and Defecation Diary}

Since the stasis of feces in the rectum can maintain constipation, it is important to evacuate the rectum frequently. In children with a developmental age of $\geq 4$ years, this can be established by introducing a toilet-training program. Toilet training involves sitting on the toilet for $5 \mathrm{~min}$ after each meal to actively try to defecate. By going to the toilet after a meal, the patient takes advantage of the gastrocolic reflex that increases colonic peristalsis upon distension of the stomach, facilitating defecation.

The importance of a relaxed posture during defecation should be explained. To ensure a relaxed posture, foot support (by means of a footstool) is needed for children whose feet do not touch the floor when they are sitting on the toilet. To motivate a child for toilet training, a reward system can be introduced, where small gifts (e.g., stickers) are earned for completing toilet trainings. A daily stool diary can help to objectify the bowel pattern of children with FC. This diary also has a motivating purpose and is a helpful tool to evaluate treatment.

\subsection{Dietary Fiber, Fluid, and Physical Activity}

It has been suggested that children with FC might benefit from additional dietary fiber, extra fluid intake, and/or increased physical activity. These three interventions are discussed below.

\subsubsection{Fiber}

The normal dietary fiber requirements of children vary from child to child and are age dependent; in children older than 2 years of age, a minimal dietary fiber intake of "age plus $5 \mathrm{~g}$ " is usually recommended [30,31]. A fiber intake below normal limits is associated with FC [32]. Several randomized controlled trials (RCTs) on the effect of dietary fiber in children have been performed [33-37]. However, these studies have used different definitions and outcome measures, and a recent systematic review applying Grading of Recommendations Assessment, Development and Evaluation (GRADE) has shown the overall quality of the evidence to be low [38].
Therefore, normal fiber intake is recommended, but current evidence does not support the use of extra fiber supplements in children with FC with a sufficient dietary fiber intake $[15,38]$.

\subsubsection{Fluid}

As with fiber, normal fluid requirements vary from child to child [39]. One study regarding extra fluid intake in children with FC showed insufficient evidence of an advantageous effect on FC symptoms [15, 40]. Therefore, extra fluid intake in children with FC who already have a normal fluid intake is not recommended [15].

\subsubsection{Physical Activity}

A large prospective birth-cohort study demonstrated that physical activity is associated with a decreased risk of having FC at the preschool stage [41]. However, no RCTs on the effect of increased physical activity on FC in children have been performed [15].

\subsection{Behavioral Therapy}

Behavioral problems occur in approximately one third of patients with FC [42, 43]. This has led to the idea that behavioral therapy might be a therapeutic option in these children. However, in an RCT, behavioral therapy had no advantage over conventional treatment with laxatives in treating childhood constipation [15, 44]. Nevertheless, when behavioral problems are present, behavioral therapy or referral to mental health services, in addition to laxative treatment, should be considered [44].

\subsection{Biofeedback Training}

Approximately $50 \%$ of children with FC have abnormal defecation dynamics [25]. Biofeedback training employs reinforcing stimuli and thereby aims to achieve a recognizable sensation with an appropriate response in children with FC. The long-term goal is to teach children to recognize the sensation by themselves. Several RCTs have assessed the effect of biofeedback training on FC in children. However, there were significant methodological differences between these studies, which makes it difficult to compare them, and the current evidence does not support the use of biofeedback training for the treatment of childhood constipation $[15,45]$.

\section{Pharmacological Treatment}

Pharmacological treatment for FC consists of treatment with laxatives and involves three steps: disimpaction, maintenance treatment, and, eventually, weaning. The 
Table 2 Pharmacological management of functional constipation in children [15]

\begin{tabular}{|c|c|}
\hline Laxative types & Dosage \\
\hline \multicolumn{2}{|l|}{ Oral laxatives } \\
\hline PEG 3350/4000 & $\begin{array}{l}\text { Maintenance: } 0.2-0.8 \mathrm{~g} / \mathrm{kg} / \mathrm{day} \text { in } 1-2 \text { doses } \\
\text { Fecal disimpaction: } 1-1.5 \mathrm{~g} / \mathrm{kg} / \mathrm{day} \\
\text { (maximum } 6 \text { days) }\end{array}$ \\
\hline Lactulose & $\begin{array}{l}7 \text { months }-18 \text { years: } 1-2 \mathrm{~g} / \mathrm{kg} / \text { day in } \\
1-2 \text { doses }\end{array}$ \\
\hline Lactitol & $\begin{array}{l}1-6 \text { years: } 0.5-1 \mathrm{~g} / \mathrm{kg} / \text { day in } 2-3 \text { doses } \\
6-12 \text { years: } 10-30 \mathrm{~g} / \text { day in } 2-3 \text { doses } \\
12-18 \text { years: } 20-60 \mathrm{~g} / \text { day in } 2-3 \text { doses }\end{array}$ \\
\hline Bisacodyl & $\begin{array}{l}3-10 \text { years: } 5 \mathrm{mg} / \text { day in } 1 \text { dose (at night) } \\
>10 \text { years: } 5-10 \mathrm{mg} / \text { day in } 1 \text { dose (at night) }\end{array}$ \\
\hline Senna & $\begin{array}{l}2-6 \text { years: } 2.5-5 \mathrm{mg} / \text { day in } 1-2 \text { doses } \\
6-12 \text { years: } 7.5-10 \mathrm{mg} / \text { day in } 1-2 \text { doses } \\
>12 \text { years: } 15-20 \mathrm{mg} / \text { day in } 1-2 \text { doses }\end{array}$ \\
\hline $\begin{array}{l}\text { Sodium } \\
\text { picosulfate }\end{array}$ & $\begin{array}{l}1 \text { month }-4 \text { years: } 2.5-10 \mathrm{mg} / \text { day in } 1 \text { dose } \\
4 \text { to } 18 \text { years: } 2.5-20 \mathrm{mg} / \text { day in } 1 \text { dose }\end{array}$ \\
\hline $\begin{array}{r}\text { Magnesium } \\
\text { hydroxide }\end{array}$ & $\begin{array}{l}2-5 \text { years: } 0.4-1.2 \mathrm{~g} / \mathrm{day} \text { in } 1 \text { or more doses } \\
6-11 \text { years: } 1.2-2.4 \mathrm{~g} / \mathrm{day} \text { in } 1 \text { or more doses } \\
12-18 \text { years: } 2.4-4.8 \mathrm{~g} / \text { day in } 1 \text { or more doses }\end{array}$ \\
\hline \multicolumn{2}{|c|}{ Rectal laxatives/enemas } \\
\hline Bisacodyl & $\begin{array}{l}\text { 2-10 years: } 5 \mathrm{mg} / \text { day in } 1 \text { dose } \\
>10 \text { years: } 5-10 \mathrm{mg} / \text { day in } 1 \text { dose }\end{array}$ \\
\hline $\begin{array}{l}\text { Sodium lauryl } \\
\text { sulfoacetate }\end{array}$ & $\begin{array}{l}1 \text { month- } 1 \text { year: } 2.5 \mathrm{~mL} / \text { dose }(=0.5 \text { enema }) \\
1-18 \text { years: } 5 \mathrm{~mL} / \text { dose }(=1 \text { enema })\end{array}$ \\
\hline Sodium docusate & $\begin{array}{l}<6 \text { years: } 60 \mathrm{~mL} \\
>6 \text { years: } 120 \mathrm{~mL}\end{array}$ \\
\hline Sodium phosphate & $\begin{array}{l}\text { 1-18 years: } 2.5 \mathrm{~mL} / \mathrm{kg} / \mathrm{dose} \text { (maximum } \\
133 \mathrm{~mL} / \text { dose) }\end{array}$ \\
\hline \multicolumn{2}{|l|}{ Lubricant } \\
\hline $\begin{array}{l}\text { Mineral oil/liquid } \\
\text { paraffin }\end{array}$ & $\begin{array}{l}\text { Oral: } 3-18 \text { years: } 1-3 \mathrm{~mL} / \mathrm{kg} / \text { day in } 1 \text { or } \\
\text { more doses (maximum } 90 \mathrm{~mL} / \text { day) } \\
\text { Rectal: } 2-11 \text { years: } 30-60 \mathrm{~mL} / \text { day in } \\
1 \text { dose; }>11 \text { years: } 60-150 \mathrm{~mL} / \text { day in } \\
1 \text { dose }\end{array}$ \\
\hline
\end{tabular}

$P E G$ polyethylene glycol

pharmacological treatment options will be discussed below and are summarized in Table 2, including recommended dosages. A treatment algorithm is provided in Fig. 1.

\subsection{Principles of Pharmacological Treatment}

\subsubsection{Disimpaction}

Fecal impaction, defined as the presence of a large fecal mass in the rectum or abdomen, occurs in approximately $50 \%$ of children with FC [25, 46]. Removal of this fecal mass (disimpaction) is recommended prior to initiation of maintenance treatment in order to increase treatment success [47]. Pharmacological options for disimpaction consist of rectally administered enemas or temporary highdose oral polyethylene glycol (PEG; $1-1.5 \mathrm{~g} / \mathrm{kg} /$ day) for 3-6 days (with a maximum of 6 days) [48-50]. One study has compared high-dose PEG and sodium docusate enemas and found these to be equally effective for disimpaction [48]. In comparison with enemas, high-dose PEG is associated with a higher frequency of fecal incontinence during treatment; however, PEG is recommended as the first choice for disimpaction since it can be administered orally and hence is less invasive [15].

\subsubsection{Maintenance}

After successful disimpaction, maintenance therapy should be initiated to prevent re-accumulation of feces [47]. The aim of maintenance treatment is to soften the stools, which facilitates easy and frequent defecation. Several laxatives (oral and rectal), as well as stool softeners, are available for maintenance treatment. Again, PEG is the oral laxative of first choice, in a dosage of $0.2-0.8 \mathrm{~g} / \mathrm{kg} /$ day. Other therapeutic options are discussed below. Depending on the severity of the symptoms, the effect of treatment should be evaluated 1-2 weeks after initiation of treatment. Maintenance treatment should be continued for at least 2 months, and FC symptoms should be resolved for at least 1 month before weaning is initiated. It is recommended that symptoms are evaluated again 2 months after cessation of treatment, to prevent or detect relapses.

\subsubsection{Weaning}

Approximately $50 \%$ of children with FC on maintenance treatment can stop using their medication within 6-12 months after initiation of treatment [51]. Maintenance medication should be gradually reduced, rather than abruptly discontinued, in order to prevent a relapse [52]. Weaning can be considered when symptoms are stable under maintenance treatment, which means that children have a defecation frequency of $\geq 3$ times per week and do not fulfill any other Rome III criteria.

\subsection{Osmotic Laxatives}

Osmotic laxatives are the first step in the pharmacological treatment of FC. They are poorly absorbed by the intestinal wall, which leads to intraluminal accumulation of hyperosmolar particles. This stimulates retention of water in the intestinal lumen, softening the stools and increasing peristalsis through intestinal distension. Furthermore, some osmotic laxatives increase peristalsis through a decrease in intraluminal $\mathrm{pH}$ [53]. The most frequently used osmotic laxatives are discussed below. 
Fig. 1 Flowchart of evaluation and management of functional constipation in children.

${ }^{1}$ Ensure adequate fiber and fluid intake. ${ }^{2}$ Polyethylene glycol (PEG) is recommended as the first choice for disimpaction. ${ }^{3}$ Medications and dosages can be found in Table 2. ${ }^{4} \mathrm{PEG}$ is recommended as the first choice for maintenance treatment. ${ }^{5}$ The first evaluation should be scheduled after 2 weeks

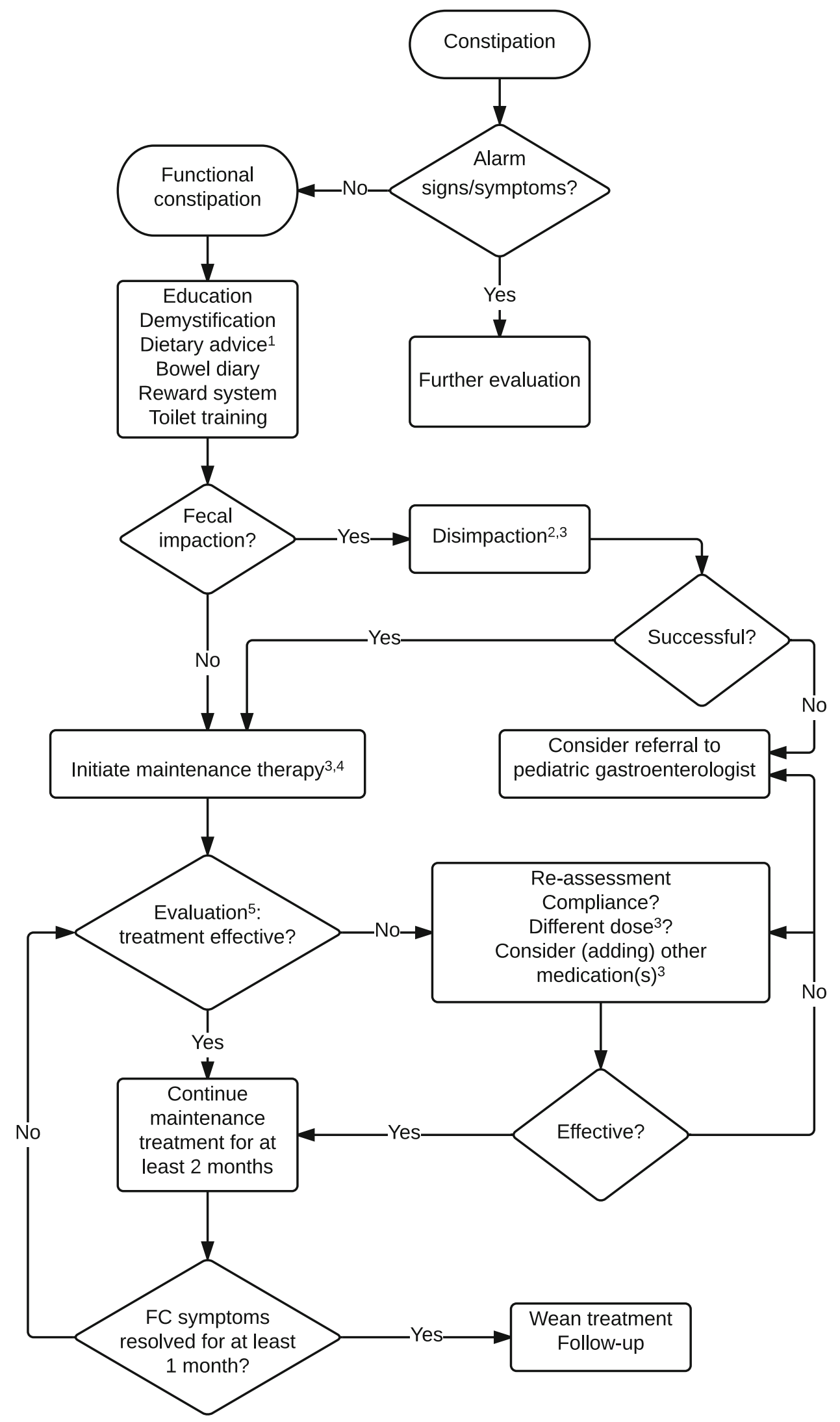




\subsubsection{Polyethylene Glycol}

PEG (or macrogol) is the first-choice osmotic laxative in children with FC. It is a linear polymer, in which water molecules are retained by means of hydrogen connections, causing an intraluminal fluid volume increase. It is not metabolized and is minimally $(<1 \%)$ absorbed in the intestine [54]. Different types of PEG have been developed-PEG 3350 and PEG 4000, with molecular weights of 3.350 and $4.000 \mathrm{~g} / \mathrm{mol}$, respectively. To minimize the risk of disturbing the electrolyte balance by osmosis, a combination of PEG with electrolytes can be used, which is iso-osmotic instead of hypo-osmotic. PEG has been proven to be more effective in increasing stool frequency $(\geq 3$ times per week) than placebo, lactulose, and magnesium hydroxide in the treatment of constipation [53, 55-57]. The use of PEG is effective and safe, even in young children (aged $<2$ years) [57-62]. Therefore, PEG is the osmotic laxative of first choice in children with FC. The effect of PEG usually occurs within 1-2 days; when fecal impaction is being treated, this effect might be delayed and may take up to 3 days. Side effects include fecal incontinence (especially during disimpaction), flatulence, abdominal pain, nausea, and abdominal bloating. In patients predisposed to water and electrolyte balance disturbances (patients with impaired hepatic or renal function, or patients taking diuretics), laboratory electrolyte checks should be considered.

\subsubsection{Lactulose and Lactitol}

Lactulose and lactitol are synthetic derivatives of lactose. These hyperosmolar agents are not hydrolyzed by digestive enzymes in the small intestine and are, for that reason, poorly absorbed by the intestinal mucosa. In the colon, these disaccharides are fermented into hyperosmolar low molecular weight acids by intraluminal bacteria [63]. This results in intraluminal water retention and a decrease in intraluminal $\mathrm{pH}$, which induces an increase in colonic peristalsis. The bacterial fermentation of these agents also leads to formation of gas, which induces additional intestinal distension and increases peristalsis. The effect of lactulose and lactitol is usually observed within a number of days. Side effects of lactulose and lactitol are usually mild and include flatulence, abdominal pain, and abdominal bloating. Chronic use can lead to electrolyte balance disturbances.

Although lactulose is often prescribed to children with FC, evidence supporting the use of lactulose in clinical practice is scarce. Moreover, lactulose has been demonstrated to be less effective than liquid paraffin or PEG in outcomes of stool frequency per week, consistency, relief of abdominal pain, and need for additional medication [53,
55]. No statistically significant difference in treatment success between lactulose and lactitol, lactulose and senna, or lactulose and dietary fiber has been found [53]. Since lactulose is considered to be safe for all ages, it is recommended in case PEG is not available.

\subsubsection{Magnesium Hydroxide (Milk of Magnesia)}

The antacid magnesium hydroxide (also referred to as "milk of magnesia" in its suspension form) and other magnesium salts (e.g., magnesium sulfate and magnesium citrate) have a laxative effect. This effect is considered to derive from the osmotic gradient that is caused by these poorly absorbed hyperosmolar agents. The effect of magnesium hydroxide occurs after $2-8 \mathrm{~h}$, whereas the effect of magnesium sulfate occurs after $1-3 \mathrm{~h}$. When the effect of PEG on stool frequency per week was compared with that of magnesium hydroxide in children with FC, a statistically significant result was found, favoring PEG [53]. Side effects include diarrhea, hypotension, weakness, and lethargy. Severe renal impairment is a contraindication for the use of magnesium hydroxide.

\subsection{Stimulant Laxatives}

If osmotic laxatives alone prove to be insufficient in the treatment of pediatric patients with FC, stimulant laxatives can be considered as additional or second-line treatment. Stimulant laxatives act directly on the intestinal mucosa, stimulating intestinal motility and/or increasing water and electrolyte secretion. Diphenylmethanes and anthraquinones are stimulant laxatives and are often used in the treatment of FC in children, although literature to support these treatments are lacking [63-65]. Even though abdominal pain is a common side effect, stimulant laxatives are often well tolerated. They are considered to be safe and effective, and can be used in the treatment of FC in children [66].

\subsubsection{Diphenylmethanes}

Diphenylmethanes include bisacodyl and sodium picosulfate-both non-absorbable agents. In the colon, diphenylmethanes are hydrolyzed to their active metabolites, which exert a local prokinetic effect and stimulate intestinal secretion [63]. Bisacodyl can be administered orally or rectally. The laxative effect of ingested bisacodyl generally occurs within $6-8 \mathrm{~h}$; therefore it is recommended to administer oral bisacodyl ante noctum. Rectally administered bisacodyl induces a fast effect (sometimes within 30-60 min). Sodium picosulfate is available only as an oral drug; the time for it to take effect is comparable to that of orally ingested bisacodyl. The most common side effects 
are abdominal pain, nausea, and diarrhea. Rectal administration of bisacodyl is contraindicated in children with proctitis or anal fissures.

\subsubsection{Anthraquinones}

Senna contains a variety of anthraquinones and is metabolized into its pharmacologically active metabolite by intestinal bacteria [63]. This metabolite stimulates colonic motility and secretion of water and electrolytes, while it inhibits absorption of water and electrolytes from the colon. Side effects include abdominal pain, nausea, diarrhea, and flatulence. In young children, senna may potentially cause severe diaper rash, blisters, and skin sloughing, and it should therefore only be used in children aged $\geq 1$ year [67].

\subsection{Lubricants}

Lubricants are a class of laxatives that mainly soften or lubricate stools.

\subsubsection{Mineral Oil}

Mineral oil (or liquid paraffin) is a derivative of petroleum. It is not absorbed by the intestines, and it functions as a lubricant. Mineral oil may also exert an osmotic effect when it is converted to fatty acids $[65,68]$. It can be administered orally or rectally; the laxative effect generally occurs within 1-2 days for both administration routes.

There have been a few low-quality trials comparing mineral oil with oral laxatives in the treatment of childhood constipation. Two studies compared mineral oil with lactulose [69, 70]; a meta-analysis revealed a significant improvement in stool frequency, although the quality of the evidence was low [53]. Liquid paraffin was also compared with PEG, which revealed no significant difference in treatment response (defined as an increase in bowel movements and a decrease in fecal incontinence frequency) between both groups [71]. In comparison with senna, liquid paraffin was shown to significantly improve the defecation frequency and fecal incontinence episodes; however, the evidence was of low quality [72].

Liquid paraffin is considered to be safe and efficacious in the treatment of FC in children [68]. However, liquid paraffin may leak out of the anus, causing irritation or itching of the skin, and it may stain clothing or furniture. Liquid paraffin can reduce absorption of fat-soluble vitamins (A, D, E, and $\mathrm{K}$ ), although this is rarely clinically relevant. There have been incidental reports of severe side effects, such as granulomata following absorption, and lipoid pneumonia following aspiration [68, 73, 74]. The
Committee on Safety of Medicines has therefore recommended that liquid paraffin should not be administered to children under 3 years of age [68].

\subsubsection{Docusate}

Sodium docusate is a mainly rectally administered therapeutic agent, although oral products exist. The surfaceactive properties of sodium docusate instigate retention of water in the stools, which renders its lubricating effect [63, 75]. There is no evidence that docusate is effective in pediatric patients with FC. Side effects are seldom reported but include diarrhea and rectal discomfort.

\subsection{Enemas}

Enemas are rectally administered fluids, which contain chemically active agents that influence gut motility, agents that exert an osmotic effect, or a combination of both. The effect of enemas is usually seen within minutes after administration. A number of different enemas are used in the treatment of FC in children. Sodium lauryl sulfoacetate brings about a redistribution of the water that is bound to hard feces and exerts a softening effect on feces. This enema does not have an osmotic effect and is usually used in infants. Sodium docusate enemas contain docusate, sometimes with added sorbitol, a hyperosmolar agent that attracts water. Sodium phosphate enemas contain a strong hyperosmolar phosphate solution. PEG and enemas have been proven to be equally effective in achieving disimpaction, but PEG is recommended because of the more invasive nature of enemas [15, 48]. Evidence does not support addition of enemas to chronic use of laxatives in children with constipation [15]. The most common side effects of enemas are abdominal pain and anorectal discomfort. Sodium phosphate enemas are contraindicated if Hirschsprung's disease is suspected, since they have the potential to induce hyperphosphatemia.

\subsection{Rectal Irrigation}

Transanal rectal/colonic irrigation is a procedure where water is infused into the rectum and/or colon to mechanically clean out the intestine. Rectal irrigation was shown to be effective in the management of fecal incontinence due to constipation in children with neurogenic defecation disorders (e.g., spina bifida or Hirschsprung's disease) or anorectal malformations [76-82]. However, data on the effectiveness of transanal irritation in children with FC are scarce [83]. Irrigations are usually performed with a volume of $10-20 \mathrm{~mL} / \mathrm{kg}$ of water, with the frequency depending on the patient's response [76,83]. 


\subsection{Novel Therapies (Lubiprostone, Linaclotide, and Prucalopride)}

Lubiprostone, linaclotide, and prucalopride are relatively new drugs, which have been found to be effective in constipated adults [84]. However, data on the efficacy of these agents in the treatment of childhood constipation are scarce or lacking.

Lubiprostone and linaclotide both promote secretion of chloride-rich fluid in the intestine, thereby softening stools and enhancing stool volume. Lubiprostone is a prostaglandin E1 derivative, which activates chloride channel subtype 2 (ClC-2). A pilot study has been conducted, evaluating the effect of lubiprostone in childhood constipation; the results suggested that lubiprostone significantly increases bowel movements and is well tolerated in children and adolescents with FC [85]. Side effects include nausea, vomiting, diarrhea, and abdominal pain [85]. Linaclotide is a synthetic peptide, which activates the luminal guanylin receptor on enterocytes and thereby promotes fluid secretion. To date, no randomized studies on the efficacy of linaclotide have been published in children. In adults, the most frequently reported adverse effect of linaclotide is diarrhea [84, 86, 87].

Prucalopride is a selective, high-affinity 5-hydroxytryptamine (serotonin) receptor 4 agonist, which enhances motility in the gastrointestinal tract [88]. In an open-label, non-controlled, 8-week study, treatment with prucalopride had a favorable effect on stool frequency, stool consistency, and fecal incontinence frequency [89]. However, in a recently published European multicenter double-blind RCT in children with constipation, prucalopride was no more effective than placebo in increasing the stool frequency or decreasing the fecal incontinence frequency. Reported adverse effects include headache, nausea, abdominal pain, and diarrhea [88].

\subsection{Probiotics}

Over the past decades, advances in culture-independent techniques have led to the discovery that in and on the human body, bacterial cells outnumber human cells by an estimated factor of ten [90-92]. The detection of species that could not be detected previously by culture-based methods has initiated the uncovering of the human microbiome, demonstrating novel concepts that could significantly alter the way we treat disease and promote health in the future [93]. The exact relationship between gut microbiota alterations and FC is still incompletely understood. However, by altering the gut microbiota, probiotics are able to influence colonic motility. Bacterial production of short-chain fatty acids lowers the $\mathrm{pH}$ in the colon, which enhances colonic peristalsis and thereby decreases the CTT
[94]. Studies on the use of probiotics have been conducted in children, but, to date, there is insufficient evidence to support the use of probiotics in the treatment of childhood constipation [38, 95].

\section{Prognosis and Follow-Up}

A large proportion of children with FC can be treated effectively with the therapeutic agents that are currently available. Pijpers et al. [51] conducted a systematic review of prospective follow-up studies on the prognosis of FC in the hospital setting (pediatrics and pediatric gastroenterology). On the basis of these largely heterogeneous studies, they concluded that within 6-12 months, approximately $50 \%$ of the children with FC had recovered and were taken off laxatives. An additional $10 \%$ of patients were free of symptoms on medication, and another $40 \%$ would still be symptomatic despite the use of laxatives [51]. After a follow-up period of 5-10 years, $56.0 \% \pm 11.3 \%$ of the children had recovered and were no longer taking laxatives. In tertiary care centers, these numbers are similar: $50 \%$ of children referred to a pediatric gastroenterologist have recovered after 5 years, with the vast majority of patients no longer taking laxatives, and after 10 years, $80 \%$ of children have recovered [15]. However, in the remainder of the children, symptoms may persist into adolescence or even adulthood, despite laxative treatment [96-98].

Early adequate therapeutic intervention is of key importance in the management of childhood FC, since a delay between the onset of symptoms and the first presentation at the department of pediatric gastroenterology is negatively related to recovery [98].

In children with severe intractable constipation that is unresponsive to intensive pharmacological treatment, referral to a specialized pediatric gastroenterology and motility center for further evaluation is recommended. In these children, surgical management may be indicated as a treatment of last resort $[15,99]$.

\section{Conclusions}

Childhood constipation is a common healthcare problem worldwide. The diagnosis is based on the history and a physical examination, in accordance with the Rome III criteria. Additional investigations are required only in situations in which the diagnosis is not clear, and in order to rule out an underlying disease. Non-pharmacological management involves education, demystification, a toilet program with a reward system, and a daily bowel diary. Pharmacological treatment with laxatives consists of 
disimpaction, maintenance treatment, and eventually weaning off medication. PEG is the laxative of first choice for both disimpaction (high-dose: $1-1.5 \mathrm{~g} / \mathrm{kg} /$ day) and maintenance treatment $(0.2-0.8 \mathrm{~g} / \mathrm{kg} /$ day $)$. If PEG is not available or is poorly tolerated, lactulose is recommended. Stimulant laxatives (bisacodyl, senna, sodium picosulfate), magnesium hydroxide, and/or mineral oil may be considered as second-line or additional treatment if treatment with osmotic laxatives is insufficient. Maintenance treatment should be continued for at least 2 months, and FC symptoms should be resolved for at least 1 month before a gradually reduction of the medication. The long-term prognosis is moderate even if early adequate therapeutic interventions are applied.

\section{Compliance with Ethical Standards}

Conflict of interest I.J.N. Koppen, L.A. Lammers, M.A. Benninga and M.M. Tabbers declare no conflicts of interest.

Funding No sources of funding were used to support the writing of this manuscript.

Open Access This article is distributed under the terms of the Creative Commons Attribution-NonCommercial 4.0 International License (http://creativecommons.org/licenses/by-nc/4.0/), which permits any noncommercial use, distribution, and reproduction in any medium, provided you give appropriate credit to the original author(s) and the source, provide a link to the Creative Commons license, and indicate if changes were made.

\section{References}

1. Mugie SM, Benninga MA, Di Lorenzo C. Epidemiology of constipation in children and adults: a systematic review. Best Pract Res Clin Gastroenterol. 2011;25:3-18.

2. Dehghani SM, Kulouee N, Honar N, Imanieh M-H, Haghighat M, Javaherizadeh $\mathrm{H}$. Clinical manifestations among children with chronic functional constipation. Middle East J Dig Dis. 2015;7:31-5.

3. Faleiros FT, Machado NC. Assessment of health-related quality of life in children with functional defecation disorders. J Pediatr (Rio J). 2006;82:421-5.

4. Voskuijl WP, van der Zaag-Loonen HJ, Ketel IJ, Grootenhuis MA, Derkx BH, Benninga MA. Health related quality of life in disorders of defecation: the Defecation Disorder List. Arch Dis Child. 2004;89:1124-7.

5. Bongers MEJ, Benninga MA, Maurice-Stam H, Grootenhuis MA. Health-related quality of life in young adults with symptoms of constipation continuing from childhood into adulthood. Health Qual Life Outcomes. 2009;7:20.

6. Clarke MCC, Chow CS, Chase JW, Gibb S, Hutson JM, Southwell BR. Quality of life in children with slow transit constipation. J Pediatr Surg. 2008;43:320-4.

7. Kaugars AS, Silverman A, Kinservik M, Heinze S, Reinemann L, Sander M, et al. Families' perspectives on the effect of constipation and fecal incontinence on quality of life. J Pediatr Gastroenterol Nutr. 2010;51:747-52.

8. Belsey J, Greenfield S, Candy D, Geraint M. Systematic review: impact of constipation on quality of life in adults and children. Aliment Pharmacol Ther. 2010;31:938-49.
9. Silverman AH, Berlin KS, Di Lorenzo C, Nurko S, Kamody RC, Ponnambalam A, et al. Measuring health-related quality of life with the Parental Opinions of Pediatric Constipation Questionnaire. J Pediatr Psychol. 2015. doi:10.1093/jpepsy/jsv028.

10. Baker SS, Liptak GS, Colletti RB, Croffie JM, Di Lorenzo C, Ector $\mathrm{W}$, et al. Constipation in infants and children: evaluation and treatment. A medical position statement of the North American Society for Pediatric Gastroenterology and Nutrition. J Pediatr Gastroenterol Nutr. 1999;29:612-26.

11. Choung RS, Shah ND, Chitkara D, Branda ME, Van Tilburg MA, Whitehead WE, et al. Direct medical costs of constipation from childhood to early adulthood: a population-based birth cohort study. J Pediatr Gastroenterol Nutr. 2011;52:47-54.

12. Ansari H, Ansari Z, Lim T, Hutson JM, Southwell BR. Factors relating to hospitalisation and economic burden of paediatric constipation in the state of Victoria, Australia, 2002-2009. J Paediatr Child Health. 2014;50:993-9.

13. Liem O, Harman J, Benninga M, Kelleher K, Mousa H, Di Lorenzo C. Health utilization and cost impact of childhood constipation in the United States. J Pediatr. 2009;154:258-62.

14. Rasquin A, Di Lorenzo C, Forbes D, Guiraldes E, Hyams JS, Staiano A, et al. Childhood functional gastrointestinal disorders: child/adolescent. Gastroenterology. 2006;130:1527-37.

15. Tabbers MM, DiLorenzo C, Berger MY, Faure C, Langendam MW, Nurko S, et al. Evaluation and treatment of functional constipation in infants and children: evidence-based recommendations from ESPGHAN and NASPGHAN. J Pediatr Gastroenterol Nutr. 2014;58:258-74.

16. Castiglia PT. Constipation in children. J Pediatr Health Care. 2001;15:200-2.

17. Mugie SM, Di Lorenzo C, Benninga MA. Constipation in childhood. Nat Rev Gastroenterol Hepatol. 2011;8:502-11.

18. McKeown C, Hisle-Gorman E, Eide M, Gorman GH, Nylund CM. Association of constipation and fecal incontinence with attentiondeficit/hyperactivity disorder. Pediatrics. 2013;132:e1210-5.

19. Peeters B, Noens I, Philips EM, Kuppens S, Benninga MA. Autism spectrum disorders in children with functional defecation disorders. J Pediatr. 2013;163:873-8.

20. Van Dijk M, de Vries G-J, Last BF, Benninga MA, Grootenhuis MA. Parental child-rearing attitudes are associated with functional constipation in childhood. Arch Dis Child. 2014;100:329-33.

21. Lane MM, Czyzewski DI, Chumpitazi BP, Shulman RJ. Reliability and validity of a modified Bristol Stool Form Scale for Children. J Pediatr. 2011;159(437-41):e1.

22. Van Der Plas RN, Benninga MA, Redekop WK, Taminiau JA, Buller HA. How accurate is the recall of bowel habits in children with defaecation disorders? Eur J Pediatr. 1997;156:178-81.

23. Lahoti SL, McClain N, Girardet R, McNeese M, Cheung K. Evaluating the child for sexual abuse. Am Fam Physician. 2001;63:883-92.

24. Benninga MA, Buller HA, Staalman CR, Gubler FM, Bossuyt $\mathrm{PM}$, van der Plas RN, et al. Defaecation disorders in children, colonic transit time versus the Barr-score. Eur J Pediatr. 1995; 154:277-84 (1995/04/01 ed.).

25. Benninga MA, Voskuijl WP, Taminiau JAJM. Childhood constipation: is there new light in the tunnel? J Pediatr Gastroenterol Nutr. 2004;39:448-64.

26. De Lorijn F, van Wijk MP, Reitsma JB, van Ginkel R, Taminiau JAJM, Benninga MA. Prognosis of constipation: clinical factors and colonic transit time. Arch Dis Child. 2004;89:723-7.

27. Belkind-Gerson J, Tran K, Di Lorenzo C. Novel techniques to study colonic motor function in children. Curr Gastroenterol Rep. 2013; 15:335

28. Berger MY, Tabbers MM, Kurver MJ, Boluyt N, Benninga MA. Value of abdominal radiography, colonic transit time, and rectal 
ultrasound scanning in the diagnosis of idiopathic constipation in children: a systematic review. J Pediatr. 2012;161(44-50):e1-2.

29. Van der Plas RN, Benninga MA, Taminiau JA, Büller HA. Treatment of defaecation problems in children: the role of education, demystification and toilet training. Eur J Pediatr. 1997;156:689-92.

30. Dwyer JT. Dietary fiber for children: how much? Pediatrics. 1995;96:1019-22.

31. Williams CL, Bollella M, Wynder EL. A new recommendation for dietary fiber in childhood. Pediatrics. 1995;96:985-8.

32. Morais MB, Vítolo MR, Aguirre AN, Fagundes-Neto U. Measurement of low dietary fiber intake as a risk factor for chronic constipation in children. J Pediatr Gastroenterol Nutr. 1999;29: 132-5.

33. Castillejo G, Bulló M, Anguera A, Escribano J, Salas-Salvadó J. A controlled, randomized, double-blind trial to evaluate the effect of a supplement of cocoa husk that is rich in dietary fiber on colonic transit in constipated pediatric patients. Pediatrics. 2006;118:e641-8.

34. Kokke FTM, Scholtens PAMJ, Alles MS, Decates TS, Fiselier TJW, Tolboom JJM, et al. A dietary fiber mixture versus lactulose in the treatment of childhood constipation: a double-blind randomized controlled trial. J Pediatr Gastroenterol Nutr. 2008; 47:592-7.

35. Quitadamo P, Coccorullo P, Giannetti E, Romano C, Chiaro A, Campanozzi A, et al. A randomized, prospective, comparison study of a mixture of acacia fiber, psyllium fiber, and fructose vs polyethylene glycol 3350 with electrolytes for the treatment of chronic functional constipation in childhood. J Pediatr. 2012; 161(710-5):e1.

36. Loening-Baucke V, Miele E, Staiano A. Fiber (glucomannan) is beneficial in the treatment of childhood constipation. Pediatrics. 2004;113:e259-64.

37. Weber TK, Toporovski MS, Tahan S, Neufeld CB, de Morais MB. Dietary fiber mixture in pediatric patients with controlled chronic constipation. J Pediatr Gastroenterol Nutr. 2014;58: 297-302.

38. Tabbers MM, Benninga MA. Constipation in children: fibre and probiotics. Systematic review 303. BMJ Clin Evid. 2015. http:// clinicalevidence.bmj.com/x/systematic-review/0303/overview.html. Accessed 28 July 2015.

39. European Food Safety Authority. Scientific opinion on dietary reference values for water. EFSA J. 2010;8(3):1459.

40. Jennings A, Davies GJ, Costarelli V, Dettmar PW. Dietary fibre, fluids and physical activity in relation to constipation symptoms in pre-adolescent children. J Child Health Care. 2009;13:116-27.

41. Driessen LM, Kiefte-de Jong JC, Wijtzes A, de Vries SI, Jaddoe VWV, Hofman A, et al. Preschool physical activity and functional constipation: the Generation R Study. J Pediatr Gastroenterol Nutr. 2013;57:768-74.

42. Benninga MA, Voskuijl WP, Akkerhuis GW, Taminiau JA, Buller HA. Colonic transit times and behaviour profiles in children with defecation disorders. Arch Dis Child. 2004;89:13-6.

43. Van Dijk M, Benninga MA, Grootenhuis MA, Last BF. Prevalence and associated clinical characteristics of behavior problems in constipated children. Pediatrics. 2010;125:e309-17.

44. Van Dijk M, Bongers MEJ, de Vries G-J, Grootenhuis MA, Last BF, Benninga MA. Behavioral therapy for childhood constipation: a randomized, controlled trial. Pediatrics. 2008;121: e1334-41.

45. Rao SSC, Benninga MA, Bharucha AE, Chiarioni G, Di Lorenzo C, Whitehead WE. ANMS-ESNM position paper and consensus guidelines on biofeedback therapy for anorectal disorders. Neurogastroenterol Motil. 2015;27:594-609.

46. Tabbers MM, Boluyt N, Berger MY, Benninga MA. Constipation in children. BMJ Clin Evid. 2010;4:303.
47. Tabbers MM, Boluyt N, Berger MY, Benninga MA. Clinical practice: diagnosis and treatment of functional constipation. Eur $\mathrm{J}$ Pediatr. 2011;170:955-63.

48. Bekkali N-L-H, van den Berg M-M, Dijkgraaf MGW, van Wijk MP, Bongers MEJ, Liem O, et al. Rectal fecal impaction treatment in childhood constipation: enemas versus high doses oral PEG. Pediatrics. 2009;124:e1108-15.

49. Youssef NN, Peters JM, Henderson W, Shultz-Peters S, Lockhart DK, Di Lorenzo C. Dose response of PEG 3350 for the treatment of childhood fecal impaction. J Pediatr. 2002;141:410-4.

50. Candy DCA, Edwards D, Geraint M. Treatment of faecal impaction with polyethelene glycol plus electrolytes $(\mathrm{PGE}+\mathrm{E})$ followed by a double-blind comparison of PEG $+\mathrm{E}$ versus lactulose as maintenance therapy. J Pediatr Gastroenterol Nutr. 2006;43:65-70.

51. Pijpers MAM, Bongers MEJ, Benninga MA, Berger MY. Functional constipation in children: a systematic review on prognosis and predictive factors. J Pediatr Gastroenterol Nutr. 2010; 50:256-68.

52. Felt B, Wise CG, Olson A, Kochhar P, Marcus S, Coran A. Guideline for the management of pediatric idiopathic constipation and soiling. Arch Pediatr Adolesc Med. 1999;153:380-5.

53. Gordon M, Naidoo K, Akobeng AK, Thomas AG. Cochrane review: osmotic and stimulant laxatives for the management of childhood constipation. Evid Based Child Health. 2013;8:57-109.

54. Brady CE, DiPalma JA, Morawski SG, Santa Ana CA, Fordtran JS. Urinary excretion of polyethylene glycol 3350 and sulfate after gut lavage with a polyethylene glycol electrolyte lavage solution. Gastroenterology. 1986;90:1914-8.

55. Lee-Robichaud H, Thomas K, Morgan J, Nelson RL. Lactulose versus polyethylene glycol for chronic constipation. Cochrane Database Syst Rev. 2010;(7):CD007570.

56. Treepongkaruna $S$, Simakachorn N, Pienvichit $P$, Varavithya $W$, Tongpenyai Y, Garnier P, et al. A randomised, double-blind study of polyethylene glycol 4000 and lactulose in the treatment of constipation in children. BMC Pediatr. 2014;14:153.

57. Chen S-L, Cai S-R, Deng L, Zhang X-H, Luo T-D, Peng J-J, et al. Efficacy and complications of polyethylene glycols for treatment of constipation in children: a meta-analysis. Medicine (Baltimore). 2014;93:e65.

58. Pashankar DS, Bishop WP, Loening-Baucke V. Long-term efficacy of polyethylene glycol 3350 for the treatment of chronic constipation in children with and without encopresis. Clin Pediatr (Phila). 2003;42:815-9.

59. Michail S, Gendy E, Preud'Homme D, Mezoff A. Polyethylene glycol for constipation in children younger than eighteen months old. J Pediatr Gastroenterol Nutr. 2004;39:197-9.

60. Loening-Baucke V. Polyethylene glycol without electrolytes for children with constipation and encopresis. J Pediatr Gastroenterol Nutr. 2002;34:372-7.

61. Loening-Baucke V, Krishna R, Pashankar DS. Polyethylene glycol 3350 without electrolytes for the treatment of functional constipation in infants and toddlers. J Pediatr Gastroenterol Nutr. 2004;39:536-9.

62. Pashankar DS, Loening-Baucke V, Bishop WP. Safety of polyethylene glycol 3350 for the treatment of chronic constipation in children. Arch Pediatr Adolesc Med. 2003;157:661-4.

63. Hoekman DR, Benninga MA. Functional constipation in childhood: current pharmacotherapy and future perspectives. Expert Opin Pharmacother. 2013;14:41-51.

64. Price KJ, Elliott TM. What is the role of stimulant laxatives in the management of childhood constipation and soiling? Cochrane Database Syst Rev. 2001;(3):CD002040.

65. Plunkett A, Phillips CP, Beattie RM. Management of chronic functional constipation in childhood. Paediatr Drugs. 2007;9:33-46. 
66. Wald A. Is chronic use of stimulant laxatives harmful to the colon? J Clin Gastroenterol. 2003;36:386-9.

67. Spiller HA, Winter ML, Weber JA, Krenzelok EP, Anderson DL, Ryan ML. Skin breakdown and blisters from senna-containing laxatives in young children. Ann Pharmacother. 2003;37:636-9.

68. Sharif F, Crushell E, O’Driscoll K, Bourke B. Liquid paraffin: a reappraisal of its role in the treatment of constipation. Arch Dis Child. 2001;85:121-4.

69. Urganci N, Akyildiz B, Polat TB. A comparative study: the efficacy of liquid paraffin and lactulose in management of chronic functional constipation. Pediatr Int. 2005;47:15-9.

70. Farahmand F. A randomised trial of liquid paraffin versus lactulose in the treatment of chronic functional constipation in children. Acta Med Iran. 2007;45:183-8.

71. Rafati M, Karami H, Salehifar E, Karimzadeh A. Clinical efficacy and safety of polyethylene glycol 3350 versus liquid paraffin in the treatment of pediatric functional constipation. Daru. 2011;19:154-8.

72. Sondheimer JM, Gervaise EP. Lubricant versus laxative in the treatment of chronic functional constipation of children: a comparative study. J Pediatr Gastroenterol Nutr. 1982;1:223-6.

73. Bandla HP, Davis SH, Hopkins NE. Lipoid pneumonia: a silent complication of mineral oil aspiration. Pediatrics. 1999;103:E19.

74. Zanetti G, Marchiori E, Gasparetto TD, Escuissato DL, Soares Souza A. Lipoid pneumonia in children following aspiration of mineral oil used in the treatment of constipation: high-resolution CT findings in 17 patients. Pediatr Radiol. 2007;37:1135-9.

75. Van Wering HM, Tabbers MM, Benninga MA. Are constipation drugs effective and safe to be used in children? A review of the literature. Expert Opin Drug Saf. 2012;11:71-82.

76. Pacilli M, Pallot D, Andrews A, Downer A, Dale L, Willetts I. Use of Peristeen ${ }^{\circledR}$ transanal colonic irrigation for bowel management in children: a single-center experience. J Pediatr Surg. 2014;49:269-72 (discussion 272).

77. Choi EK, Han SW, Shin SH, Ji Y, Chon JH, Im YJ. Long-term outcome of transanal irrigation for children with spina bifida. Spinal Cord. 2014;53:216-20.

78. Marte A, Borrelli M. Transanal irrigation and intestinal transit time in children with myelomeningocele. Minerva Pediatr. 2013;65:287-93.

79. Choi EK, Shin SH, Im YJ, Kim MJ, Han SW. The effects of transanal irrigation as a stepwise bowel management program on the quality of life of children with spina bifida and their caregivers. Spinal Cord. 2013;51:384-8.

80. Corbett P, Denny A, Dick K, Malone PS, Griffin S, Stanton MP. Peristeen integrated transanal irrigation system successfully treats faecal incontinence in children. J Pediatr Urol. 2014;10:219-22.

81. Alenezi H, Alhazmi H, Trbay M, Khattab A, Neel KF. Peristeen anal irrigation as a substitute for the MACE procedure in children who are in need of reconstructive bladder surgery. Can Urol Assoc J. 2014;8:E12-5.

82. Märzheuser S, Grauel F, Rothe K. Treatment for fecal incontinence in patients with anorectal malformations. Introduction of a therapeutic approach [in German]. Pflege Z. 2013;66:612-5.
83. Nasher O, Hill RE, Peeraully R, Wright A, Singh SJ. Peristeen ${ }^{\circledR}$ transanal irrigation system for paediatric faecal incontinence: a single centre experience. Int J Pediatr. 2014;2014:954315.

84. Ford AC, Suares NC. Effect of laxatives and pharmacological therapies in chronic idiopathic constipation: systematic review and meta-analysis. Gut. 2011;60:209-18.

85. Hyman PE, Di Lorenzo C, Prestridge LL, Youssef NN, Ueno R. Lubiprostone for the treatment of functional constipation in children. J Pediatr Gastroenterol Nutr. 2014;58:283-91.

86. Love BL, Johnson A, Smith LS. Linaclotide: a novel agent for chronic constipation and irritable bowel syndrome. Am J Health Syst Pharm. 2014;71:1081-91.

87. Parker $\mathrm{CH}$, Yuan Y, Liu LWC. Linaclotide: a new option for the treatment of irritable bowel syndrome with constipation and chronic idiopathic constipation in adults. Clin Med Insights Gastroenterol. 2013;6:21-32.

88. Diederen K, Mugie SM, Benninga MA. Efficacy and safety of prucalopride in adults and children with chronic constipation. Expert Opin Pharmacother. 2015;16:407-16.

89. Winter HS, Di Lorenzo C, Benninga MA, Gilger MA, Kearns GL, Hyman PE, et al. Oral prucalopride in children with functional constipation. J Pediatr Gastroenterol Nutr. 2013;57:197-203.

90. Johnson CL, Versalovic J. The human microbiome and its potential importance to pediatrics. Pediatrics. 2012;129:950-60.

91. Turnbaugh PJ, Ley RE, Hamady M, Fraser-Liggett CM, Knight R, Gordon JI. The Human Microbiome Project. Nature. 2007;449:804-10.

92. Wopereis H, Oozeer R, Knipping K, Belzer C, Knol J. The first thousand days-intestinal microbiology of early life: establishing a symbiosis. Pediatr Allergy Immunol. 2014;25:428-38.

93. Hayashi H, Sakamoto M, Benno Y. Phylogenetic analysis of the human gut microbiota using $16 \mathrm{~S}$ rDNA clone libraries and strictly anaerobic culture-based methods. Microbiol Immunol. 2002;46:535-48.

94. Chmielewska A, Szajewska H. Systematic review of randomised controlled trials: probiotics for functional constipation. World $\mathrm{J}$ Gastroenterol. 2010;16:69-75.

95. Korterink JJ, Ockeloen L, Benninga MA, Tabbers MM, Hilbink M, Deckers-Kocken JM. Probiotics for childhood functional gastrointestinal disorders: a systematic review and meta-analysis. Acta Paediatr. 2014;103:365-72.

96. Michaud L, Lamblin M-D, Mairesse S, Turck D, Gottrand F. Outcome of functional constipation in childhood: a 10-year follow-up study. Clin Pediatr (Phila). 2009;48:26-31.

97. Van Ginkel R, Reitsma JB, Büller HA, van Wijk MP, Taminiau JAJM, Benninga MA. Childhood constipation: longitudinal follow-up beyond puberty. Gastroenterology. 2003;125:357-63.

98. Bongers MEJ, van Wijk MP, Reitsma JB, Benninga MA. Longterm prognosis for childhood constipation: clinical outcomes in adulthood. Pediatrics. 2010;126:e156-62.

99. Siminas S, Losty PD. Current surgical management of pediatric idiopathic constipation: a systematic review of published studies. Ann Surg. 2015. doi:10.1097/SLA.0000000000001191. 